\title{
LEGAL IMPLICATION OF THE AUDIT BOARD OF INDONESIA ON MANAGEMENT AUDIT AND FINANCIAL LIABILITY OF THE STATE AGAINST STATE-OWNED ENTERPRISES
}

\author{
Henny Juliani \\ Faculty of Law, Diponegoro University \\ hennyjuliani.fhundip@gmail.com
}

\begin{abstract}
The objectives of tis research is to find out implication of BPK (Auditor Board of Republic of Indonesia) in the implementation of auditing and responsibility of state finance which is manage by state own company as regulated by national regulations. This study used normative juridical and analytic descriptive approach. The study indicated that BPK has authorities to conduct finance audit and control and ask responsibility to BUMN management board because assets of BUMN is belonged to state assest although the assests is separated, it cannot be converted to be BUMN assest. Its juridical implication, there is not transformation from state finance to private finance in managing separated state assests, consequently BPK as independent external auditor has authority to audit professionally.
\end{abstract}

Keywords : BPK, Audit of Management and Accountability of State finance, State-owned Enterprise

\section{Introduction}

The state financial management system was established according to the Article 23(1) of the 1945 Constitution of the Republic of Indonesia which asserts that : "The State Budget as the basis of the management of state funds shall be determined annually by the law and shall be implemented in an open and accountable manner in order to best atten the prosperity of the people." Furthermore, in Article 23C of the Constitution also asserts that : "Other matters concerning state finance shall be further regulated by the law." Later, the government implemented policies in 3 Acts as a further steps taken on state finance management, which are the Law No.17/2003 on State Finance (State Finance Act), the Law No.1/2004 on State Treasury (State Treasury Act), and the Law No.15/2004 on the Audit of Management and Accountability of State Finance.

The state financial management is an entire action taken for financial management which includes planning, implementation, supervision and accountability. The state financial management was implemented by officials according to their scope of authority. A good management on state finance shall be impacted to people's prosperity, therefore, needs an independent body authorized to such duties. 
Article 23E of the 1945 Constitution is a constitutional basis for the establishment of the Audit Board or BPK which authorized to audit the management and accountability of state finance. Furthermore, the Audit Board procedure and authority scope was regulated in the Law No.15/2006 on Audit Board (Audit Board Act).

The Audit Board as an independent body, is responsible to supervised the state financial management in order to attain an accountable and clean government from corruption and nepotism. In article 3(1) of the Audit Board Act, the Audit Board have a broad scope of supervision authority on every aspects of state finance as regulated in the State Finance Act. Therefore, the Audit Board was also authorized to do supervision on state-owned enterprises, according to article 2(g) of the Audit Board Act that mentioned state finance includes every state or regional assets which privately supervised by the state or other party such as money, negotiable instrument, credits, goods, or other tradable instrument which includes a separate assets of state or regional-owned enterprises.

The state-owned enterprise have a strategic role in public service, as a balancer to private business in competition, and supports micro businesses. State-owned enterprise is also one of the main source of the state revenue in forms of taxes, dividends, and acquisitions. Therefore, for a such important role of the State-owned Enterprise as a driving force of national economy, as the Government "extension" on executing policies and programs. State-owned enterprise besides as public servant, also important as development agent. This research intends to seek the implication of the Audit Board duties of management and accountability supervision of state finance on state-owned enterprise according to the law.

\section{Discussion}

According to Paragraph IV of the Preamble of the 1945 Constitution, the Republic of Indonesia had adopted the concept of welfare state. In a welfare state, the Government had entrusted the role of bestuurzorg or common welfare exertion. ${ }^{1}$ In practice, the mainstreaming of the public interest is in line with the concept of democracy that has become the goal of the Indonesian nation since its inception in 1945. The concept of democracy is a paradigm shift of power in a political community from the state-oriented state center to people center). ${ }^{2}$ Under the

\footnotetext{
${ }^{1}$ SF. Marbun and Moh. Mahfud MD. 1987. Pokok-Pokok Hukum Administrasi Negara, Yogyakarta, Liberty, hal. 45

${ }^{2}$ Kristian Widya Wicaksono. 2014. Telaah Kritis Administrasi dan Manajemen Sektor Publik di Indonesia. Yogyakarta. Penerbit Gaya Media. Hal. vii
} 
legal provisions, officials only perform the functions and authority, because officials have no authority. Who has and is approached by authority is the position. ${ }^{3}$

According to Philipus M. Hadjon, the responsibility of officials in performing their functions is differentiated between the responsibilities of office and personal responsibility. Responsibilities of office with respect to the legality (legitimacy) of government action. In administrative law, the question of the legality of governmental acts is related to the approach to governmental power. Personal responsibility is related to a functional approach or behavioral approach in administrative law. Personal responsibility regarding maladministration in the use of authority or public service. The distinction between the responsibilities of the office and personal responsibility for the acts of government brings consequences relating to criminal liability, civil liability and administrative accountability (TUN). Criminal liability is personal responsibility. In connection with governmental acts, an officer's personal responsibility is due to maladministration. Civil liability may be a claim of office in respect of unlawful acts by the authorities. Civil liability becomes a personal liability if there is an element of maladministration. The accountability of the TUN is essentially a claim of office. ${ }^{4}$

According to Budi Setiyono, the existence of public corporations or state owned enterprises / state-owned state-owned enterprises (SOEs) historically, is an integral part of the public sector in many countries. This is because the government has instruments in the form of production, where SOEs become government production units that sell products in the market process. $^{5}$

As a legal entity, BUMN also plays a role in advancing the welfare of all Indonesian people as mandated by the 1945 Constitution of the State of the Republic of Indonesia (NRI) Article 33. In this connection, SOEs shall exercise the mandate of the Constitution on the control of national economic power based on economic democracy and as a state through state ownership To certain business units with a view to providing the greatest benefit to the welfare of the people. Thus SOE has a dual function, namely as a business entity that is profit oriented as well as also serves as an agent of development. ${ }^{6}$

\footnotetext{
${ }^{3}$ Julista Mustamu, Diskresi dan Tanggung Jawab Administrasi Pemerintahan, Jurnal Sasi Vol. 17 No. 2 Bulan April-Juni 2011 ${ }^{4}$ Philipus M. Hadjon, dkk. 2011. Hukum Administrasi dan Tindak Pidana Korupsi, Yogyakarta. Gadjah Mada University Press. Hal. 16-17

${ }^{5}$ Budi Setiyono. 2014. Pemerintahan dan Manajemen Sektor Publik. Yogyakarta. CAPS. Hal. 161

${ }^{6}$ Henny Juliani, Masalah-Masalah Hukum Jilid 44 No. 3 Juli 2015. Fakultas Hukum Universitas Diponegoro. Semarang. Hal. 291
} 
Indroharto in Ridwan HR stated that BUMN / BUMD are included as "government agencies". A different opinion is expressed by Arifin P. Soeria Atmadja which confirms that the legal status of Persero (BUMN) is purely a civil legal entity, as well as business relations arranged according to civil law and does not have state facilities. Nomenclature applicable to governmental agencies is not valid at the Persero, including the legal status of Persero employees including the directors are regular private employees. ${ }^{7}$

According to Arifin P. Soeria Atmadja, the building of public finance architecture basically shows a tiered financial pattern and establishing a clear and definite management and supervision network, so as to differentiate the rules of management and accountability. In the building of public finance architecture, SOE finance has its own legal capacity that is different from other legal entities. The governance and governance of BUMNs has a civil law capacity in which the provisions governing it are civil laws and regulations. The State, in its capacity to the State-Owned Enterprise, is the subject of civil law, whose original legal action in the form of duty and authority (taak en bevoegdheid) has been transformed into rights and obligations (bekwaamheid) as a result of a horizontal transaction entirely subject to the civil law regime. ${ }^{8}$

With that in mind, theoretically legal, state or state institutions have no public authority in the SOEs because there has been a change of function and transformation of the legal status of wealth/finance in SOEs, from duty and authority (taak en bevoegdheid) as a public legal entity, Obligations as a result of horizontal transactions and the transformation of the legal status of state money into civil money, essentially becoming a solid basis to strengthen the rights and obligations of SOEs as legal entities. ${ }^{9}$

In carrying out its duties and authorities, the manager of SOEs needs to be monitored in order for the work to be carried out in accordance with the established plan or the desired result. Supervision is the final part of the management function. Supervision can be viewed from various aspects, such as economic or management aspects and legal aspects. In terms of management, supervision is needed to ensure that an organization's activities run in accordance with the plan (planning) so that organizational goals are achieved. In addition, supervision is also to keep government functions running well and guaranteed the implementation of good governance (good governance). Thus, monitoring can minimize the constraints that occur and immediately make improvements. ${ }^{10}$

\footnotetext{
${ }^{7}$ Ridwan HR. 2013. Hukum Administrasi Negara. Jakarta. Raja Grafindo Persada, hal. 84

${ }^{8}$ Arifin P. Soeria Atmadja. 2013. Keuangan Publik dalam Perspektif Hukum. Jakarta. Rajawali Press. Hal. 119-120

${ }^{9}$ Ibid. Hal. 34

${ }^{10}$ SF. Marbun. 2013. Hukum Administrasi Negara II. Yogyakarta. FH UII Press. Hal. 2
} 
Paul Effendie Lotulung said that when viewed from the aspect of the position of the body/organ that carries out supervision on the body/organ under supervision, it can be distinguished into internal control and external control. Internal control means that the oversight is done by a body that is organically / structurally still within the government itself. On the other hand, an external supervision is an oversight done by organ or institution that is organically / structurally outside the government in the sense of the executive, for example, financial supervision conducted by BPK. ${ }^{11}$

According to Muhammad Djafar Saidi, the examination is a legal action in the context of supervision of the management and responsibility of state finances. The examination shall not deviate from the provisions of its guidance, so as not to cause harm to the parties examined. Conversely, the parties examined have the obligation to provide verbal information and written statements relating to information or alleged misuse of state finances, such as showing the bookkeeping or recording as the basis for the management of state finances. ${ }^{12}$

The changes of society also has impact in the social life, which is according to the development of society from simple community and homogenized becames complex and heterogeneous, as explained by Sir Henry Maine. ${ }^{13}$

The terminology of state finance according to Article 1(1) of the State Finance Act (Law No.17/2003) is every state rights and duties in which valuable, as well as every instrument such as money or goods that the state could be owned according to such rights and duties. Also in Article 2(g) of State Finance Act asserts that the state finance includes every state or regionalowned assets that managed privately or by other parties such as money, negotiable instrument, credits, goods, or another valuable due, includes separate assets of state or regional-owned enterprises.

The Audit Board of the Republic of Indonesia is a state-established commission that authorized to supervise the management and accountability of state finances. As the Audit Board was established as an independent body, therefore, the Board was positioned as an external supervisor to the Government.

Duties and functions of the Audit Board were regulated in Article 6 (1) of the Audit Board Act (Law No. 19/2003), which asserts:

\footnotetext{
${ }^{11}$ Paulus Effendie Lotulung. 1986. Beberapa Sistem tentang Kontrol Segi Hukum Terhadap Pemerintah. Jakarta. Bhuana Ilmu Populer. Hal. XV

${ }^{12}$ Muhammad Djafar Saidi. 2013. Hukum Keuangan Negara. Jakarta. Raja Grafindo Persana. Hal. 80

${ }^{13}$ Siti Malikhatun Badriyah. "Justice A Yearning In the Implementation of The Contract of the Society". In Diponegoro Law Review.Vol 2. April 2017.No. 1. Pp 154 - 167
} 
"The Audit Board served to supervise management and accountability of state finance which enacted by the State Government, Regional Government, other governmental bodies, Indonesia Bank, State-Owned Enterprise, Public Services, RegionalOwned Enterprise, and other bodies authorized on state finance management."

This duty is a follow-up enforcement of Article 1(1) of the Law No.19/2003 on StateOwned Enterprise (State-owned Enterprise Act) which defines state-owned enterprise as business entity with the state owned the entire or partial ownership of capital through direct addition from separated state assets. Furthermore, in Article 1(10) of the State-owned Enterprise Act, the separated state assets is assets in State Budget which used for addition of state capital for limited, public, or another kind of corporations.

The Audit Board guideline on managing state financial accountability and management was regulated in the Law No.15/2004 on Management and Accountability of State Finance. The Board scope was also regulated in Article 2 until 5. In Article 2(1), the state financial audit includes auditing on state financial management and accountability. In Article 3(1), the scope of state finance which supervised by the Audit Board comprehend the definition of state finance in Article 2 of State Finance Act. In Article 4(1), the supervision or audit includes supervision on finance, performance, or other specified means. The financial audit is a supervision on financial reports. Performance audit supervises economic efficiency of the management system. And the audit for other specified means is another supervision which has not included in former articles, which in the Elucidation of the Act asserts that other specified audit includes finance investigation and audit on the government control system.

Article 16 of the Audit Board Act asserts that the audit from the Board could be resulted in 3 forms, which are opinion, recommendation, and conclusion. In the Elucidation of Article 16, opinion is a professional statement of auditor on the fairness of information in finance report which based on four categories : (1) suitability with government accountancy standard, 2) adequate disclosures, (3) legal conformity and (4) internal control effectivity. There are four kind on opinions : (1) unqualified opinion, (2) qualified opinion, (3) adversed opinion and (4) disclaimer of opinion.

The Audit Board authority as a state financial supervision body was reinforced through the Decision of the Constitutional Court of the Republic of Indonesia No.62/PUU-XI/2013. In the Decision, the Court advised that the separation of state assets can not be interpreted as rupturing the responsibility of the government with its enterprises (state/regional owned enterprise). Such separation was done in order to ease the management of business entities to be fit in the 
competition and enacting capital accumulation, which needs immediate decision-making process, so the truth could be accounted.

The State-owned, regional-owned or other similar enterprises are different with private business entity and other non-business state administration bodies. However, state-owned enterprises and similars also on duty of state financial management, in which suited to be onchecked constitutionally by the Audit Board and People's Representative Council, even though both using different supervision principles.

In other words, the Article 6(1) of the Audit Board Act is also an opened legal policy mandated by the Constitution to the lawmakers to the extent its related to state financial management. The legal subject of the Audit Board supervision is all management bodies on state finance, whether it directly managed or separated.

The constitutional Court asserts in decision that the separation of state assets were intended to be seen as transaction was not diverting due of assets from the state into its enterprise. Therefore, the Audit Board still have authority to do supervision to state or regional-owned enterprise assets. However, as the state-owned enterprises complied the good corporate governance principle, therefore, its internal supervisor such as commisarries and supervisory board are still relevant to have such authority.

The constitutional court was also considered another matter, which is the paradigm of state/regional-owned enterprises as the state's authority extension, in the context of business judgement rules. The context was, in fact, really different than government judgement rules. State assets was transformed as a capital for its enterprises which in management context, were abide to the business judgement rules. However, the separation of state assets did not made enterprise assets became detached from state assets. This occured because the perspetive of transaction only applied on detachment which cannot be interpreted as ownership diversion, therefore, the state authority as supervisor of its assets was still prevail. However, this supervisory paradigm of the state must be changed, which did not based on principles of government judgement rules, but instead as business judgement rules.

The constitutional court decision had break down Arifin Soeria Atmadja statement which asserts that there was a transformation of legal status on state assets in state-owned enterprises became a civil commercial money and vice versa. He stated that the state in its position as public legal subject has authority (bevoegdheid) to assigned decision on separating the state finance to support capital for enterprise establishment. When the money has been transferred to state- 
owned enterprise via stocks and after the enterprise legalized as legal subject, likewise, legal standing of the state cannot representing itself as public legal subject. Such a thing must be understand in the context of affirmative private law. Hence, the detachment of burden and liability of the state or the risk as public legal subject in state-owned enterprise. The legal standing of state as stockholder is equal to other private stockholder. Hence, the state must fully abide to the prevailing system in civil law context so that its immunity from public liability is gone. ${ }^{14}$

\section{Conclusion}

From the research, it can be concluded that the state-owned enterprises which its capital was owned entirely or partially by the state is also the extension of state authority in order to exercise some of state duties. State assets, therefore, had transformed as enterprise capital which management abide to business paradigm or business judgement rules. However, the separation of state assets did not detached state-owned enterprise assets from state assets. Hence, there is no transformation of assets legal standing from public law to private law. This matter is juridically impacted to the Audit Board authority as a finance supervisory body which also authorized to exercised its authority to state-owned enterprise. The audit consists of financial audit, performance audit, and specified audits. The report from the Audit Board supervisory contains opinions, reports, conclusions, and reccommendations. The Audit Board was, juridically, strengthened its position on supervisory authority through the decision of constitutional court No.62/PUU-XI/2013, which implicated the Audit Board authority in a professional manner.

\section{References}

Atmadja, Arifin P. Soeria, (2013), Keuangan Publik dalam Perspektif Hukum, Edisi Ketiga, Jakarta :Rajawali Press , (2014), Aktualisasi Hukum Keuangan Publik, Bandung : Mujahid Press

Badriyah. Siti Malikhatun . "Justice A Yearning In the Implementation of The Contract of the Society”. In Diponegoro Law Review.Vol 2. No. 1.April 2017.

Hadjon, Philipus M. dkk, (2011), Hukum Administrasi dan Tindak Pidana Korupsi, Yogyakarta :Gadjah Mada University Press

HR, Ridwan, (2013), Hukum Administrasi Negara, Jakarta : PT Raja Grafindo Persada.

${ }^{14}$ Arifin P. Soeria Atmadja, op. Cit, hal. 35-36 
Juliani, Henny, Masalah-masalah Hukum Jilid 44 No.3, Juli 2015, Fakultas Hukum Universitas Diponegoro, Semarang;

Lotulung, Paulus Effendie, (1986), Beberapa sistem tentang Kontrol Segi Hukum terhadap Pemerintah, Jakarta : PT. Bhuana Ilmu Populer

Makawimbang, Hernold Ferry, (2014), Kerugian Keuangan Negara, Yogyakarta: Thafa Media

Marbun, SF dan Moh. Mahfud MD, (1987), Pokok-pokok Hukum Administrasi Negara, Yogyakarta : Liberty

Marbun, SF, (2013), Hukum Administrasi Negara II, Yogyakarta :FH UII Press

Mustamu, Julista, Diskresi dan Tanggung Jawab Administrasi Pemerintahan, Jurnal Sasi Vol.17 No.2 Bulan April-Juni 2011;

Saidi, Muhammad Djafar, (2011). Hukum Keuangan Negara, Edisi Revisi, Jakarta : PT Raja Grafindo Persada.

Setiyono, Budi, (2014). Pemerintahan dan Manajemen Sektor Publik, Yogyakarta :CAPS

Soemitro, Ronny Hanitijo, (1994)., Metodologi Penelitian Hukum dan Yurimetri, Jakarta: Ghalia lndonesia.

Tjandra, W Riawan. (2008), Hukum Administrasi Negara, Yogyakarta, Penerbit Universtas Atmajaya

Wicaksono, Kristian Widya,( 2014), Telaah Kritis Administrasi dan Manajemen Sektor Publik di Indonesia, Yogyakarta, Penerbit Gava Media.

Undang-Undang Dasar Negara Republik Indonesia Tahun 1945;

Undang-Undang Nomor 17 Tahun 2003 tentang Keuangan Negara;

Undang-Undang Nomor 19 Tahun 2003 tentang Badan Usaha Milik Negara;

Undang-Undang Nomor 1 Tahun 2004 tentang Perbendaharaan Negara;

Undang-Undang Nomor 15 Tahun 2004 tentang Pemeriksaan Pengelolaan dan Tanggung Jawab Keuangan Negara;

Undang-Undang Nomor 15 Tahun 2006 tentang Badan Pemeriksa Keuangan; 